た。

以上の実験で次の結果を得た，

1. 根管充媜剂の細胞抑制作用は，高漊度のものほど 抑制率が高く，毒性の濃度依存性が認められた。

2. 5 つの検体中 4 つの検体で, 培養後半に増殖の回 復現象や再活性化が認められた。

3. 各薬剤の $50 \%$ 阻濃度 (I.D 50) は， ヨードホル

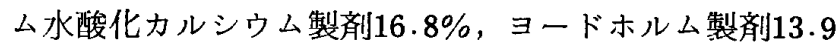
$\%$ ，水酸化カルシウムグアヤコールホルムアルデヒド製 剂1.0\%酸化亜鈆ユージノール製剂7.4\%であった。

\section{7.ラット舌下神経凍結による末梢神経分布の変化につ いて}

\section{野田 邦治・龟山 軎光・山田 長敬} (九歯大 $\cdot 1$ 口外)

凍結外科の口腔外科領域における応用は, 病変が体表 近くに存在するととにより, その利用頻度は高く, 粘膜 疾患, 良性・悪性新生物の紐胞破壊が直視下で出来るた め好結果を得ており，臨床において安定した評価を受け ている

凍結外科侵襲が口腔組織に及ぼす影響については，口 腔粘膜，顎骨に関する報告は多く見られるが，神経組織 について言及したものは少ない。

今回, 演者らは, 凍結外科が末梢神経線維に及ぼす影 響をラット舌下神経を用いて神経病理学的観察を行い， いささかの知見を得た。

凍結には Spenbly 社の DFS-30型を使用, $-100 \mathrm{C}^{\circ}$ にて，ラット舌下神経を凍結, 術直後より 2 力月まで, 50匹について神経病理学的検索を行なった。

その結果, 術後 1 日目より神経の変性が始まり，3日 目が最も著明で，14日目まで見られた。一方，再生は， 20 日目でシュワン氏細胞の著明な増殖と微細な神経線維 を認めた。このことから, 反応は遅いが, 凍結外科の場 合も，外科的神経切断と同様な経過をたどるととが明ら かとなった。

\section{8. 骨吸収に関する研究 第 1 報 マクロファージの㴽} 発法について

$\begin{array}{ll}\text { 岩永 伸子・井上 } & \text { 博雅・安 秉根 } \\ \text { 内山 長司 } & \text { (九粷大・口細) } \\ \text { 小山田 守 } & \text { (九雪大・進学) }\end{array}$

米周疾患において炎症局所におけるマクロファーシ
$(\mathrm{M} \phi)$ による種々の免疫反応が生体防御に 重要である ことは周知のことである．料槽骨の吸収に関しては破骨 細胞の関与が重視されている．最近 M $\phi$ が破骨細胞の前 駆細胞であること， $\mathbf{M} \phi$ 自身が骨吸収をおこすととが報

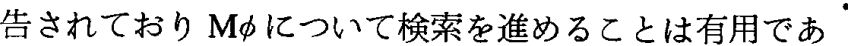
ると思われる。

実験には ICR 系マウスを用いその腹腔内に細菌內毒 素（LPS） $10 \mu \mathrm{g}$ またはペプトン $200 \mathrm{mg}$ を投与し，3日 後にイーグル MEM で腹腔内を洗浄し浸出細胞を採取 した. $37 \mathrm{C} ， 5 \% \mathrm{CO}_{2}$ 下で30分間培養後 $10 \%$ 仔牛血清 加 MEM と上清を交換しその後 $5 \mathrm{hr}$ まで経時的に観察 した。福富らと同様に $\mathrm{M} \phi$ を大きく 3 形態に分類し経 時的な形態別分布と特徽的機能を調べた．

形態は円形のAタイプ，細く伸びた Bタイプ，形質の 広がったCタイプに分類された. LPS 誘発 M $\phi$ もへプ トン誘発 $\mathrm{M} \phi$ も経時的に $\mathrm{A}$ が減少し， B，C は増加し たＬPS ではペプトンに比へ培養初期より B， Cが多 かった.このことは LPS の M $\phi$ 活性化と関連があり， 最初 Aの形態をしていた B，CがLPS により早期に B，Cへと移行すると考えられる. また形態別に LPS

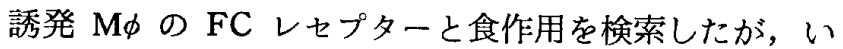
ずれもCタイプに陽性細胞が多かった．CタイプはLPS により活性化を受けやすくそのため免疫能の指標である 両機能が亢進したと考えられる.との他に M $\phi$ の骨に対 する直接作用として骨片からの Ca 溶出量を経時的に測 定したが培養 $5 \mathrm{hr}$ までに有意な溶出はみられなかっ た。

今後は 3 タイプを分離する条件を検討して $\mathrm{M} \phi$ を分 離し，それぞれについてさらに長時間培養した場合の Ca 溶出量を測定し, 骨に対する 直接作用について検討 する予定である.さらに腹腔 $\mathrm{M} \phi$ のみならず雨周疾患に

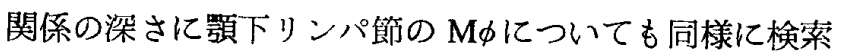
していきたいと楛えている。

\section{9. カラーレス ポーセレンの臨床応用}

\section{平川郁夫・中道 正義・内田 度也} (九歯大 $\cdot 2$ 補綴)

金属烊付ポーセレンによるクラウンやブリッジは，䦭 材の番美性と金属の両方の長所を兼的倩えたもので，広 く臨床に応用されている。

今回，(2) 1 |(1)部に金属焼付ポーセレンブリッジ，|2 にポーセレンジャケットクラウンを装着して, 術後13年 を経過した35才の女性と，(2)1|(1)部はアルミナスポーセ 
レンブリッジを装着し，術後12年を経過した女性の症例 をリコールし比較検討したところ，金属焼付ポーセレン の辺縁部二次カリエス, 歯肉の炎症及び変色は, ポーセ レンジャケックラウンに比べ強く認められる傾向にあ った。これは，金属焼付ポーセレンの場合ショルダー部 金属が鋸歯状を呈し，さらにその表面に酸化物が産生さ れ，プラークが停滞しやすいためと考えられる．一方， ポーセレンジャケットクラクンでは, 最終焼成によりシ ョルダー部陶材がわずかに丸みを帯びる傾向にあり，乙 れがポーセレンジャケットクラクンの予後を良好にする と考えられる。

そこで, 今回, 株式会社松風より開発されたポーセレ ンマージン用キットを用いたカラーレスポーセレンを教 室で基礎的研究を行い臨床面に応用した。乙れは，従来 の耐火模型や白金箔による方法に比べ，特別な材料を必 要とせず簡単である. 特對として, $980^{\circ} \mathrm{C}$ と焼成温度の 高いデンチン色陶材を瞇頸部にまず焼成し，次にボディ 陶材の焼成後, 形態修正する。ボディ陶材の焼成により ショルダー部はわずかに不適合となっており，乙の不足 部分に対し修正用 c p mパウダーを追加焼成する.その 結果，良好なショルダー部における適合が得られ，また わずかに丸みを帯びて来る。

以上の特徽を備えたカラーレスポーセレンは，いわゆ る金属焼付ポーセレンに比べ，畨頸部に強度の面で問題 はあるが，適切に作製されれば，歯肉の変色，炎症及び 二次カリェスの発生も少ないものと評価できる。

\section{0. 結核性リンパ節炎の一例}

$$
\begin{array}{llc}
\text { 大森 } & \text { 桂二・長谷川 } & \text { 健・本田 武司 } \\
\text { 古本 } & \text { 克磨 } & \text { (福歯大・2口外) } \\
\text { 沢熊 } & \text { 正明 } & \text { (福歯大・口病) }
\end{array}
$$

顎下部及び頸部りンパ節に腫脹をきたす疾患は各種炎 症性疾患をはじ悪性腫煌等が挙げられるが，中でも顎 下部及び頸部に発生する結核性リンパ節炎はその発現様 式から悪性腫瘍などとの鑑別が重要である．

今回, 私達は臨休的汇顎下唾液腺腫瘍を疑い, 病理組 織学的検索の結果, 結核性リンパ節炎喨の断を得た 1 例 を経験した。

症例：40才，女性. 初亮：昭和57年11月30日。主泝： 左側䫟下部の無痛性腫脹，家族歴：父親が前立腺癌で死 亡. 生活歴：特記事項なし. 現病歴：昭和57年11月 20 日 ごろより, 左側頜下部の腫脹に気付き，漸時増大傾向を 示したため医科を受診し，紹介により当科を受診した。
現症：左側效下三角部で一下顎骨体下縁に近接した 部位 に, クルミ大の腫脹を認め, 弾性硬で周囲組織に対して 可動性を有する腫瘤を触知し，同部に軽度の圧痛を認め た、口腔内において，特に異常所見はない，X線所見： 特に異常所見は諗めず, また左側額下唾液腺造影でも異 常所見は認めなかった. 処置：左側顎下腺腫痬の疑いに て, 全身麻酔下で, 顎下部腫瘤摘出術を施行した。摘出 物所見：大きさは約 $20 \times 15 \times 13 \mathrm{~mm}$ で，表面は平滑，淡 赤色を呈していた. 病理組織学的所見：辺縁部の 1 部に 乾酪化壊死組織を認め，大部分は結核性肉芽組織で， ラ ンゲルハンス型の巨細胞が散見され，その周辺部では 類上皮細胞に富む組織像を呈していた，以上により確定 診断を結核性リンパ節炎とした。術後の経過は良好であ り，手術創の治癒を認めた後，全身的精查目的にて内科 を受燮したが，他藏器に異常を珰めず，また現在も外来 にて経過観察中であるが, 術後 6 力経過し再発等異常所 見は認めていない。

\section{1. 新規接著セメントを用いての接著ブリッジの㱏例}

\section{勝俣 辰也・宮口敞・本池 直行 松浦 哲郎・松浦 智二}

(福菌大 $\cdot 2$ 補)

菌質および金属の両者に対して強い接着性を有するレ シンの開発により，少数歯欠損で両支台囷に健康なエナ メル質が残存している場合や，因周治療後の動摇柬の症 例に対し，接着ブリッジ・スプリントが頻繁に用いられ るようになって来た，演者らは，接着強度，耐水性等に 優れ，かつ操作性の良い新規接着セメント（クラレ社試 作品）を昨年来, 症例们用いて良好な結果を得ている. このレジンセメントはリン酸エステル系の新規な接着性 モノマーを配合したメタアクリル系モノマーと極微細な 無機質フィラーおよび常温重合用開始郕から成るコンポ ジットレジン型のものである. 今回, 接着性ブリッジ 2 症例について報告した。

症例 1 . 25才の男性， 5 | 久損による咀緭障害を主訴 として来院． 6 | は大く近心傾斜しているが，64| 共に 骨植堅固で，歯質も健全である．維持部のデザィンは， 4|では，舌側面ならびに隣接面に維持を求め，近遠心 刃縁隆線側にレスト様維持部を設けた，6Iでは，咬合 接触していない咬合面の近心 $2 / 3$ を含む広い面を維持部之 するため舌側面ならびに遠心辺縁隆線部には維持部を設 けなかった。また補経側隣接面部をわずかに削除し回転 抵抗形態とした。金属は $\mathrm{Ni}-\mathrm{Cr}$ 合金レキシリウム IV 